\title{
An Analysis of the Impact of Sudden Events on China's Automobile Industry Stock Price
}

\author{
Xiaoyue Wang ${ }^{1}$ \\ ${ }^{1}$ Jinan University, Guangzhou, China \\ Correspondence: Xiaoyue Wang, Jinan University, Guangzhou 510632, China.
}

Received: March 10, 2017

Accepted: March 21, 2017

Online Published: March 27, 2017

doi:10.20849/ajsss.v2i1.133

URL: https://doi.org/10.20849/ajsss.v2i1.133

\begin{abstract}
The occurrence of special events such as food safety, information disclosure, policy implementation and political events will have a certain impact on the relevant areas of economic and financial. This paper uses the incident research method to take the political events of the Diaoyu Islands dispute as an example to study the influence of the listed companies in the Chinese automobile industry related to the Japanese brand. The conclusion is that the occurrence of special events in the listed companies of China's automobile industry to the relevant economic performance as a substitute effect, and the occurrence of special events on the Japanese brand of the car has a negative impact, but there is a positive impact on the Chinese local brands and European and American brands of cars.
\end{abstract}

Keywords: event study, abnormal return, Japanese brand, rank test

\section{Introduction}

In recent years, China and neighboring countries, increasing friction, such as China and Vietnam, the Philippines and other countries in the South China Sea dispute, the Sino-Indian border Xinjiang region dispute, the Sino-Japanese Diaoyu Islands dispute, But in the economy along with national political disputes, with the deepening of the world economic integration, the interdependence and development of the economies of various countries, which makes us need to seriously consider the economic consequences of political conflict. On the political conflict to the macroeconomic and the influence of various industries has become one of the hotspots in economic research. On September 11, 2012, the Japanese government signed a contract to buy the Diaoyu Islands into its nationalization process, thus the Sino-Japanese Diaoyu Islands dispute intensified. Subsequently, the public appeared a strong boycott of Japanese goods, Japanese brand sales in China suddenly dropped, home appliances, aviation, tourism, the automotive industry have suffered heavy losses. Japanese brand car suffered a particularly heavy blow. At present, a large part of the literature on the Diaoyu Islands dispute on the overall macroeconomic impact of China and Japan (Kui Renzhi, 2013) there are some literature focused on the Japanese car affected by the Diaoyu Islands incident (Gao Yan, 2013; Xu Mei, 2013), these documents are mainly from the Sino-Japanese Diaoyu Islands conflict on the Japanese brand car sales were statistically described, concluded that the impact of the Diaoyu Islands incident, the Japanese car's overall sales level compared to the previous month fell by $29.5 \%$. Unfortunately, there is no literature to study in the stock market in the national conflict in the specific industry changes in the company's stock price situation, this paper pre-event study method to try Event research method in the study of the sudden impact of the company's share price is very extensive, foreign literature in the use of incident research on the impact of unexpected events in the food industry (yunhao, 2013) also have a corresponding domestic research, such as the use of (Wang Yongqin, 2014), the use of event research to study the impact of listing financing on the securities market (Hu Mengze, 2013), in the company's financial aspects of the use of event research to study the issue of melamine incident on the dairy industry Whether the impact of corporate mergers and acquisitions on the creation of value (Zhang Xin, 2003; Liu Xiaoping, 2009) and so on. At present, there are few empirical documents on the impact of political emergencies on macroeconomics, and the empirical research articles specific to the industry are scarce. The research of this paper can enrich and expand the impact of emergencies on the industry economy. China's securities market, the automotive industry to respond to the degree of validity of the information to do a test has a certain theoretical significance. Studying the impact of political conflict on the share price of the other sectors of the automotive industry helps to understand the specific economic impact of political conflicts on their own brand companies 
and on companies that are branded companies in conflict countries and third-party countries with alternative effects. In China, independent brands are mainly concentrated in low-grade, Japanese, Korean and most of the brand and part of the brand in Europe and the United States concentrated in the mid-range, and most of Europe and the United States Department of the brand focused on high-grade, if the Sino-Japanese Diaoyu Islands under the conflict in the mid-range Japanese Frustrated serious, then it belongs to the same level of Korean and Europe and the United States Department of great benefit or downgrade or upgrade their own brands and high-end brand revenue, which can further study the low-grade cars at all levels in China's competitiveness. Which can provide investment decision reference for investors in the securities market and provide reference for the company to deal with emergencies and provide policy suggestions for the development direction of China's automobile industry.

\section{Literature Review}

\subsection{A Study on Sino - Japanese Economic Relations}

At present, foreign research on Sino-Japanese economic relations mainly focuses on trade research, and most of them are carried out by Japanese scholars. Sasatra Sudsawasd (2012) has studied the development of Sino-Japanese trade from the perspective of East Asian integration. It points out that China and Japan are among the two countries with the strongest economic strength in East Asia. The key to the realization of East Asian integration is that China and Japan can resolve their differences of interests. Once the East Asian integrated economic zone is established, it will inject a tonic force for the further development of Sino-Japanese trade, Trade relations to bring a great role in promoting. But the objective is that the challenges facing the future of Sino-Japanese trade are still more. From the perspective of industrial structure, with the prospering of China's rising, the main advantages of Japan's foreign trade will be weakened, Japanese wood is undoubtedly a huge impact. At the same time, the uncertainty of Sino-Japanese political relations has also brought great risks to the development of trade relations between the two countries. Shim P. Aimstrong (2012) analyzes that the world impact of Sino-Japanese trade and Sino-Japanese trade from a political perspective. It argues that the instability of political relations is a potential risk factor affecting the development of trade between China and Japan. Whether it is a historical issue or a territorial dispute, it will cause great damage to the political relations between the two countries. Once this damage is formed, The impact on the healthy development of Sino-Japanese trade has a very negative impact, and this effect is not the government can control, often from the spontaneous behavior of the people, originated in the people's own "patriotic sentiment", the impact of each other's products In the domestic market demand, therefore, makes this effect also has a strong foundation and continuity.

China's research on this aspect is mainly to study the development of Sino-Japanese trade status, impact factors, and problem countermeasures and other content, covering a wide range. Ma Lijuan (2011) "East Asian economic integration in the context of Sino-Japanese trade relations research" It is pointed out that the economic relations between China and Japan have changed from complementary relations to interdependence, and the change of bilateral trade relations has affected the economic development in East Asia. From the development trend, the interdependent relationship is mixed with a certain amount of trade friction and trade conflict, the existence of these factors not only affected the level of Sino-Japanese trade, but also blocked the further development of Sino-Japanese trade, but these problems Is caused by the relative change in the industrial structure of the two countries. Therefore, it can only be relaxed, and can not be avoided.

\subsection{The Impact of Sino - Japanese Diaoyu Islands Conflict on the Economy of the Two Countries}

In September 10, 2012, the Japanese side announced the purchase of the Diaoyu Islands, not only quickly aroused the concern of the national political level, but also attracted wide attention from the academic community, the focus of attention for the Diaoyu Islands incident will affect China's macroeconomic. Zhang Jifeng (2013) pointed out that the Diaoyu Islands had a serious impact on Sino-Japanese economic relations, bilateral investment was hampered, trade declined significantly, Sino-Japanese mutual bond and RMB directly frustrated, China-Japan-Korea FTA negotiations failed during the year. The economic sanctions brought about by the Diaoyu Islands issue can only bring about the consequences of double losing, and should rationally look at the economic impact of political problems. There are also literatures on the Diaoyu Islands conflict on the Japanese car purchase behavior. Gao Yan (2013) that the incident can cause a significant impact on consumer behavior, thus affecting the development of different industries, Japanese cars affected by the most serious, from the consumer to buy Japanese cars from the perspective of the Japanese car sales decline Research, that the occurrence of the Diaoyu Islands incident makes the consumer's cognitive mood changes, risk awareness to arouse, and herd mentality, three aspects and boycott the purchase of Japanese cars to explain the reasons for the decline in Japanese car sales. 


\subsection{An Empirical Study on the Impact of Emergencies on the Company's Stock Price}

Event research method focuses on the impact of events such as corporate mergers and acquisitions, earnings announcements, refinancing and other events on the company's stock price, its essence is the impact of the event on the value of the enterprise in the stock price response. It has been widely used at home and abroad, there is a mature research system. In foreign countries, the event research method is widely used in the field of financial economy, in recent years with the incident research method to study the increasingly rich literature of the incident. Event research is one of the most important ways to test the effectiveness of capital markets, that is in an important position (Brown, 1980; Warner, 1985; Fama,1991). There are also many empirical papers on the validity of the application of incident law to test the effectiveness of the domestic securities market. The research literature from 1993 to 1995, such as Song Songxing and Jin Weiyin (1995), generally agreed that China's securities market was basically weak after 1993. Jin Yunhui (2001) concluded that China's securities market for the shell listed companies in terms of its overreaction, and therefore do not belong to the semi-strong effectiveness. In the corporate finance, the use of incident research to study the behavior of mergers and acquisitions ahead of the existence of early news leaks, and whether the real business acquisitions to create value for the performance of the company's share price on how to reflect, Zhang Xin (2003) in the merger and reorganization of enterprises Creating the value of the article using the event research method to draw the conclusion that the target company stock premium reached $29.05 \%$, indicating that the acquisition event for the company to bring value. In 2008 the degree of melamine incident in the domestic milk powder market was seriously affected, which attracted the attention of scholars both at home and abroad. In the literature, Mcdonald, S (2008) and yunhao (2010) studied the response of investors to food safety events with the melamine milk powder incident in China. The conclusion was that the stock price of the company was not seriously deteriorated after the incident, And the integrity of the enterprise's share price has risen sharply and benefit from the impact of unexpected events in the market institutional investors and individual small investors, the degree of response is inconsistent, institutional investors, the degree of response to small fluctuations than individual investors rational. While the domestic scholars have also studied the melamine incident, compared to foreign scholars focus is not consistent. The main purpose of the study is the competitive effect of the event on the trust market and the effect of infection. It considers that the market of the trust product is different from the general market. Taking the melamine incident as an example, if an enterprise finds the problem, it affects the other enterprises There will be two kinds of problems, one is the competitive effect, that is, the substitution effect, and the other is the adverse effect of infection, that consumers or investors will guess the same industry with the same business may have the same problem, Wang Melamine inspection of the results of the Chinese dairy market for melamine compliance of the integrity of enterprises have also been adversely affected by the performance of the stock price ,also has a certain degree of decline, indicating that the dairy market consumer and investor infection dominated the business confidence is not enough .A deeper response to the intensity of supervision is not tight enough. In addition, the event research method is also applied to the study of policy effects, Hu Mengze (2013) studied the financing of listed financing on the impact of the securities market. The conclusion is that the stock price of the listed company has the corresponding change of the stock price and the negative news respectively, and the validity of the Chinese stock market reaction to the policy information.

\section{Research Methods}

In this paper, the combination of theoretical analysis and empirical analysis of the research methods to the main empirical analysis. First of all, through the conclusion of the Sino-Japanese Diaoyu Islands conflict incident on the Chinese economy related literature to study the entry point for the Sino-Japanese Diaoyu Islands conflict on the Chinese auto industry listed companies stock price, to determine the breakdown of the content to be studied. Secondly, we study the empirical method of using the event research method to study the impact of emergencies on the stock price of listed companies. Once again, collect the relevant data of listed companies in the automotive industry, according to the steps of the incident research method to solve. Finally, the conclusion and interpretation. First, the comprehensive literature analysis proposed the following assumptions:

Hypothesis 1: Test the effectiveness of the automotive industry in the Chinese securities market for sudden response to sudden political events. The suddenness of the political class has had a significant negative impact on the share price of the automotive industry.

Hypothesis 2: China's auto industry is characterized by the introduction of foreign cars in the domestic production of automotive technology, Japanese cars because of high safety factor, high cost advantages in the country is very popular, but after the occurrence of the Diaoyu Islands people have resisted Japanese goods, The market will be the corresponding performance of the investor's tired feelings and the prospects for the production of Japanese car companies are not optimistic about the Japanese stock price is a negative excess rate of return. 
The balance of the Japanese car will make the replacement of products, that is, China's own brand cars and China and third-party countries, joint venture brand companies direct income, the performance of the stock price is positive excess rate of return.

Hypothesis 3: test whether the production of low, medium and high-end car brands of the company's stock price changes will be significantly different. In the Chinese auto market, the production of low-priced cars to independent brand companies, the production of mid-range brands in Japan and South Korea, Europe and the United States Department, which mainly in Japan, high-end brands to Europe and the United States Department of the main Japanese cars were excluded Of the case, the European and American Department of the stock yield has a significant positive impact, independent brands have significant positive excess rate of return.

\section{Data and Empirical Analysis}

In this paper, the use of incident research method, from the China Automotive Industry Yearbook and Guotaian database to find China's auto industry in the vehicle listed companies in the Sino-Japanese Diaoyu Islands before and after the occurrence of the stock price data. China's auto industry in accordance with the country For example, the Japanese, autonomous, German and mixed systems are studying the changes in their share prices, examining the effectiveness of the information response in China's auto market, the damage to the company's interest in political conflicts, and the changes in its share price by China-Japan Diaoyu Islands The impact of the length of time. On this basis, then the car is divided into low, medium and high-end brands, and then separate the various levels of the brand's share price affected by the situation.

This paper collected the entries of the listed companies in the automobile industry from the flush software and the Guotai database, and removed the five listed companies from Ankai Bus, Zhongtong Bus, Yutong Bus, Yueda Investment and Yaxing Bus. The main product is not a domestic car. And in accordance with the China Automotive Industry Yearbook in accordance with the company's technical sources of the classification of the company out of the Department, the preliminary data statistics are as follows:

\begin{tabular}{llc}
\hline Code & Company & Brand nationality (JAP=0, CHINA=1, OTHERS=2) \\
\hline 000927 & *ST 夏利 & 0 \\
\hline 601238 & 广汽集团 & 0 \\
\hline 000800 & 一汽轿车 & 1 \\
\hline 000951 & 中国重汽 & 1 \\
\hline 601777 & 力帆股份 & 1 \\
\hline 600418 & 江淮汽车 & 0 \\
\hline 600006 & 东风汽车 & 1 \\
\hline 600303 & 曙光股份 & 0 \\
\hline 600166 & 福田汽车 & 0 \\
\hline 600686 & 金龙汽车 & $2,1,0$ \\
\hline 000625 & 长安汽车 & 1 \\
\hline 601633 & 长城汽车 & 1 \\
\hline 600609 & 金杯汽车 & 1 \\
\hline 002594 & 比亚迪 & 2 \\
\hline 600104 & 上汽集团 & 1 \\
\hline 000572 & 海马汽车 & 1 \\
\hline 000550 & 江铃汽车 & \\
\hline & & \\
\hline
\end{tabular}

In addition, the daily stock market data from the wind database.

The first step in conducting an event study is to identify the time interval in which the test event is affected, the event window. Often the definition window of the event window is longer than the specific time period in which it may have an impact, such as extending the event window to several days before the event to prevent disclosure 
of information before the event is released or the delayed release of the event The This article will be the official announcement of the Japanese Diaoyu Islands(AD-110) to 2 days before the announcement date (AD - 2) is the model estimation interval for the study event, which is the date of the event study. Is the estimated period of the event study, the day before the announcement to 14 days after the announcement (AD - 14) for the event of the concern interval, that window period.

The pre-announcement period is used to verify the expected impact of the market on the results of the announcement before the event announcement and its impact. The late announcement is used to verify the continuing impact of the event announcement on the listed company for a relatively long period of time. This study uses the excess return rate AR to reflect the impact of Sino-Japanese sudden political events on the stock returns of listed companies in China's auto industry. In order to estimate the normal rate of return E (Rjt), usually the case of asset pricing model, multi-factor model and market model, this paper observes the characteristics of the scoring chart of the yield and market index yield of each automobile industry Market model:

$$
\mathrm{R}_{\mathrm{jt}}=\mathrm{a}_{\mathrm{j}}+\mathrm{b}_{\mathrm{j}} \mathrm{R}_{\mathrm{mt}}+\mathrm{e}_{\mathrm{jt}}
$$

In this paper, the representative of several types of companies to do the scatter diagram to do, are the Department of the Department of the hippocampus, Japanese-related Changan Automobile, the United States and Germany, the United States and Germany, non-Japanese-related Korean Yueda investment, these companies The yield and market index yields are shown below:
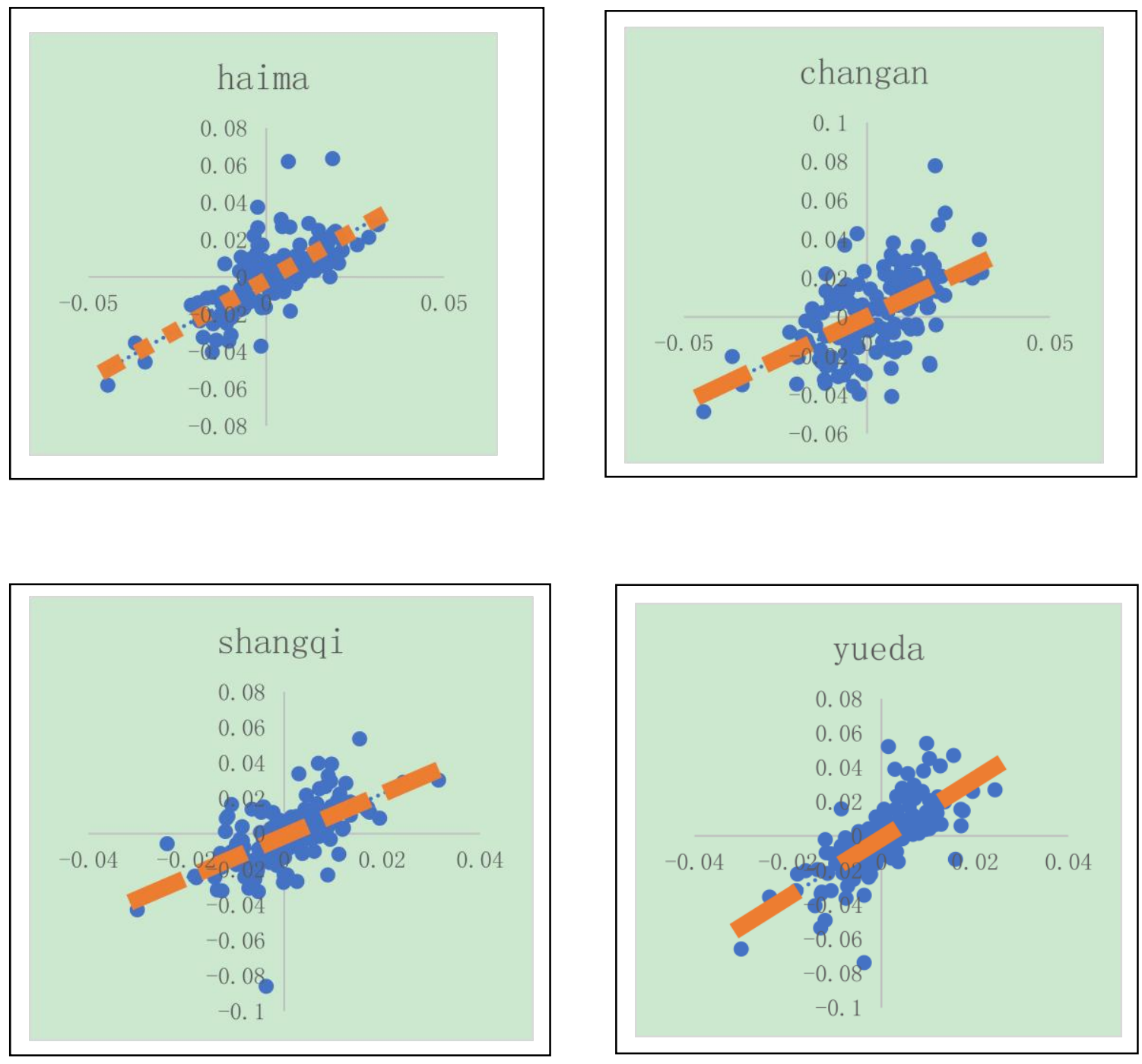
Where Rmt is the rate of return for the specified portfolio $\mathrm{m}$ in period $\mathrm{t} . \mathrm{Bj}$ is the sensitivity of the stock $\mathrm{j}$ to the market risk, and $\alpha \mathrm{j}$ is the other risk that the current period has failed to explain the return rate of the stock $\mathrm{j}$ through market reasons. Ejt is the statistical error term, $\Sigma$ ejt $=0$. Parameter estimation of aj and bj is performed by regression analysis.

The excess rate of return (Rjt) of the stock $\mathrm{j}$ at time $\mathrm{t}$ is defined as the difference between the actual rate of return $(\mathrm{Rjt})$ of the stock and the estimated value $(\mathrm{E}(\mathrm{Rjt})$ of the market pre-rate of return:

$$
A R_{j t}=E\left(R_{j t}\right)-R_{j t}
$$

Where Pjt is the closing price of stock $\mathrm{j}$, the actual return on investment ( $\mathrm{Rjt}$ ) of stock $\mathrm{j}$ is calculated by publicity (2):

$$
\mathrm{R}_{\mathrm{jt},}=\left(\mathrm{p}_{\mathrm{jt}}-\mathrm{p}_{\mathrm{jt}-1}\right) / \mathrm{p}_{\mathrm{jt}-1}
$$

In order to reflect the overall response of the securities market to a certain type of event, it is usually necessary to calculate the average excess return rate AAR for a certain type of event in the securities market. The average excess return rate of a set of $\mathrm{N}$ events at time t AARt is calculated by the formula (4):

$$
\mathrm{AAR}_{\mathrm{t}}=\frac{1}{N} \sum_{j=1}^{N} \mathrm{AR}_{\mathrm{jt}}
$$

The second step is to collect the stock price data of listed companies in China's auto industry according to the estimated period and window period, and classify them according to the purpose of the study. For the first time classified as in accordance with the company's production of automotive brand technology sources will be divided into different countries of the Department, respectively, Japanese, independent brands, third-party national brands (German, US, legal system); second classification For the company in accordance with the production of major car brands will be divided into the production of low, medium and high-end three levels of positioning.

\section{Results}

As the Sino-Japanese Diaoyu Islands political conflict in China's Japanese brand industry significantly, of which the impact of Japanese cars the most significant. So this article will be listed in China, 11 passenger car companies are divided into Japanese brands and non-Japanese brands. So the hypothesis is:

H1: Sino-Japanese Diaoyu Islands incident on China's Japanese-related passenger car companies have a significant negative impact on the yield.

Because of the small number of listed companies in this paper, the significance level of the $\mathrm{T}$ test here may be ineffective. In this paper, we use a nonparametric rank test method for small sample size tests (Carrodo, 1989). The test statistic of the structure is:

$$
\mathrm{S}^{2}\left(\mathrm{~L}_{2}\right)=\frac{1}{L 2} \sum_{i=T 1+1}^{T 2}\left(\frac{1}{N} \sum_{i=1}^{N}\left(K i t-\frac{L 2+1}{2}\right)\right)^{2}
$$

Where L2 is the length of the event window, including the estimate period and the window period, and (L2 + 1) / 2 is the rank of the non-normal event on the event day. The whole sample consists of $\mathrm{N}$ securities companies, Kit for the securities $i$ in the $t$ day of the abnormal rate of return from small to large after the rankings. The results of the mean rank test for the non-normal rate of Japanese and non-Japanese are as follows:

Table 1

\begin{tabular}{rcrrr}
\hline \multirow{2}{*}{$\begin{array}{c}\text { Event } \\
\text { window }\end{array}$} & A group & \multicolumn{2}{c}{ B group } \\
\cline { 2 - 5 } & \multicolumn{1}{c}{ AAR $_{\mathrm{t}}$} & Rank test & \multicolumn{1}{c}{ AAR $_{\mathrm{t}}$} & Rank test \\
\hline-1 & 0.0429 & $2.0854^{* * * *}$ & -0.0097 & -0.0854 \\
0 & 0.0048 & 0.3051 & 0.0246 & 0.4095 \\
1 & -0.0082 & -0.7051 & 0.0483 & 0.8012 \\
2 & -0.0004 & -0.0450 & 0.0204 & 0.0405 \\
3 & -0.0159 & $-1.2252^{*}$ & 0.0047 & 1.2320 \\
4 & 0.0179 & 1.0752 & -0.0077 & $-1.0025^{*}$
\end{tabular}




$\begin{array}{rrrrr}5 & -0.0402 & -2.0054^{* * *} & 0.0005 & 0.0144 \\ 6 & -0.0098 & -0.5451 & -0.0045 & -0.3421 \\ 7 & 0.0000 & 0.0550 & 0.0193 & 0.0685 \\ 8 & -0.0422 & -1.9153^{* * *} & 0.0829 & 2.5135^{* * *} \\ 9 & 0.0099 & -1.0439^{*} & 0.0967 & 2.7428^{* * *} \\ 10 & 0.0037 & -0.2081 & 0.0909 & 2.7002^{* * *} \\ 11 & 0.0118 & -0.9981 & 0.0189 & 0.6523 \\ 12 & -0.0173 & 0.0443 & -0.0325 & -0.0223 \\ 13 & 0.0290 & -0.7768 & -0.0413 & -0.0335 \\ 14 & 0.0379 & 0.3210 & 0.0489 & 0.5310\end{array}$

Note: $* * *$ indicates significant significance at $1 \%$ significance level, $* *$ indicates significant significance at $5 \%$ significance level, * indicates significant significance at $10 \%$ level

As shown in Table 1, this paper divides all companies listed in the passenger car industry in China into two categories. Group A is associated with Japanese and Group B is non-Japanese. The results of the rank test of group A show that Japanese companies are significantly positive at the previous day's excess rate of $1 \%$, and on day 3, day 5, day 8 after sudden political events, Day 9 was significantly negative. The results of the rank test of group B show that the excess returns of non-Japanese-related listed companies are significantly negative at the level of $10 \%$ on the fourth day after the event and at the level of $1 \%$ significantly positive.

From the results, the Japanese car stock price the day before the positive, and after the incident occurred four times a significant negative situation. First, the trend is positive, indicating that special events do have a certain impact on the Japanese brand's car's share price. Second, the sustained significant negative, indicating that the impact of special events is continued for some time, indirectly, the Chinese stock market response to information is a certain time, may not be effective with the Chinese stock market is highly relevant. The nonpering rate of non-Japanese cars was significantly negative for the fourth day, indicating that there was no substitute for Japanese cars as a result of the decline in Japanese auto prices, but the 8th, 9th and 10th consecutive days Significant significance is that the market may be the digestion of such information is lagging behind, there may be the occurrence of the event brewing and continuous fermentation period, whether Japanese brands or non-Japanese brands of cars are not in the event before the performance of The corresponding significant reaction, which is different from food safety or policy disclosure and other things, may be due to the possibility of early warning of political events less informed, insiders smaller, so there is no insider message response to the stock price. In addition, the comprehensive event occurred after the window of the excess rate of performance of the point of view, the occurrence of special events do make non-Japanese cars on the Japanese car has a certain degree of substitution.

\section{References}

Barber, B. M., Odean, T., \& Zhu, N. (2009). Do retail trades move markets?. Review of Financial Studies, 22, 151-186. https://doi.org/10.1093/rfs/hhn035

Bhabra, G. S., Harjeet, S. B., \& Glenn, W. B. (2011). Competitive and Contagion Effects in Corporate Lay-off Announcements. Journal of Money, Investment and Banking, 19, $42-54$.

Brown, S. J., \& Jerold, B. W. (1985). Using Daily Stock Returns: The Case of Event Studies. Journal of Financial Economics, 14(1), 3-31. https://doi.org/10.1016/0304-405X(85)90042-X

Campbell, C. J., \& Charles, E. W. (1993). Measuring Security Price Performance Using Daily NASDAQ Returns. Journal of Financial Economics, 1(33), 73-92. https://doi.org/10.1016/0304-405X(93)90025-7

Campbell, J., Lo, A. W., \& Mackinlay, A. C. (1997). The Econometrics of Financial Markets, Princeton University Press.

Corrado, C. J. (1989). A Nonparametric test for Abnormal Security-price Performance in Event Studies. Journal of Financial Economics, 23(2), 385-395. https://doi.org/10.1016/0304-405X(89)90064-0

Corrado, C. J., \& Terry, L. Z. (1992). The Specification and Power of the Sign Test in Event Study Hypothesis Tests Using Daily Stock Returns. Journal of Financial and Quantitative analysis, 3(27), 465-478. 
https://doi.org/10.2307/2331331

Dao, Y., Kong, D., \& Wang, M. (2010). Investor reactions to Food Safety Incidents: Evidence from the Chinese Milk Industry. Food Policy, 43(2013), 23-31.

Darby, M. R., \& Edi, K. (1973). Free Competition and the Optimal Amount of Fraud. Journal of Law and Economics, 16(1), 67-88. https://doi.org/10.1086/466756

Dulleck, U., \& Rudolf, K. (2006). On Doctors, Mechanics, and Computer Specialists: The Economics of Credence Goods. Journal of Economic Literature, 44(1), 5-42. https://doi.org/10.1257/002205106776162717

Emons, W. (1997). Credence Goods and Fraudulent Experts. Rand Journal of Economics, 28(1), 107-119. https://doi.org/10.2307/2555942

Fama, E. F. (1965). The Behavior of Stock-Market Prices. The Journal of Business, 38(1), 34-105. https://doi.org/10.1086/294743

Fama, E. F. (1970). Efficient Capital Markets: A Review of Theory and Empirical work. The Journal of Finance, 25(2), 383-417. https://doi.org/10.2307/2325486

Fama, E., Fisher, L., Jensen, M., \& Roll, R. (1969). The Adjustment of Stock Prices to New Information. International Economic Review, 10(1), 1-21. https://doi.org/10.2307/2525569

Hendricks, K. B., \& Singhal, V. R. (2003). The Effect if Supply Chain glitches on Shareholder wealth. Journal of Operations Management, 21, 501-502. https://doi.org/10.1016/j.jom.2003.02.003

Hvidkjaer, S. (2008). Small Trades and the Cross-section of Stock Returns. Review of Financial Studies, 21, 1123-1151. https://doi.org/10.1093/rfs/hhn049

Khotari, S., \&Warner, J. (2006). Econometrics of event studies. Working Paper, 12(1), 25-29.

Lee, C.M.C., \& Radhakrishna, B. (2000). Inferring Investor Behavior: Evidence from TORQ Data. Journal of Financial Markets, 3, 83-111. https://doi.org/10.1016/S1386-4181(00)00002-1

Mackinlay, A. C. (1997). Event Studies in Economics and Finance. Journal of Economic Literature, 35, 13-39.

Mcdonald, S. (2008). Nearly 53000 Chinese Children Sick from Milk. Associated Press, 22 September.

Patterson, G. A. (1992). Sears's Brennan Accepts Blame for Auto Flap. Wall Street Journal, 24(2), 134-155.

Rousseau, D. M., Sitkin, S. B., Burt, R. S., \& Camerer, C. (1998). Not So Different After All: A Cross-discipline View of Trust. Academy of Management Review, 23, 393-404. https://doi.org/10.5465/AMR.1998.926617

Selnes, F. (1998). Antecedents and Consequences of Trust and Satisfaction in Buyer-seller Relationships. European Journal of Marketing, 32, 305-322. https://doi.org/10.1108/03090569810204580

Weise, E., \& Schmit, J. (2007). FDA Limits Chinese Food Additive Imports. USA Today, 30 April.

Xiu, C., \& Klein, K. K. (2010). Melamine in Milk Products in China: Examining the Factors That Led to Deliberate Use of The Contaminant. Food Policy, 35, 463-470. https://doi.org/10.1016/j.foodpol.2010.05.001

\section{Copyrights}

Copyright for this article is retained by the author(s), with first publication rights granted to the journal.

This is an open-access article distributed under the terms and conditions of the Creative Commons Attribution license (http://creativecommons.org/licenses/by/4.0/). 